\title{
Epilogue: Consider Nijinsky
}

In 1939 Vaslav Nijinsky was visited in a Swiss hospital by press photographers. ${ }^{1}$ Years earlier Bleuler had assessed the dancer as 'a confused schizophrenic with mild manic excitement' (Acocella, 1999, p. xli). Similarly, H.G. Baynes (1940) would see Nijinsky as so archetypically schizophrenic that he could see the dancer in the drawings of leaping androgynous figures made by others. Although we may question twentieth-century schizophrenia, there is no doubting Nijinsky's troubled mental history-his own writing and diaries bear witness to it. In a garbled and sometimes incoherent letter to Jean Cocteau, written shortly after his diagnosis, signs of Nijinsky's unwellness still echo dancelike across the page: 'Mogi, cogi, togi, jogi. Migi, gigi, gi gi, rigi, Tchigi, tchigi, tchigi, rigi. Tchigi, rigi, rigi, tchigi. Migi, tigi ...' (Acocella, 1999, p. 274). This is tragic, although maybe even delightful in its rhythms for Cocteau, and somewhat fitting for a dancer, who, more than any, was never truly separated from the dance.

Asked by the photographers to reprise his famous jump Nijinsky obliged. The doctor in charge was apparently so angry he threatened to discharge Nijinsky. But records note the applause gave Nijinsky some pleasure (Acocella, 1999). In one of the photographs, later published in Paris Match and Life, a suited Nijinsky is making his jump. It is not high, but it is photographed so that he appears to levitate-with arms spread out at waist height. Behind him on the wall, he casts a great shadow that reaches to the floor. For this artificing photographer, Jean Manzon, Nijinsky had simultaneously left his split personality behind and revealed it. Yet, for us, he appears to have jumped right out of a twentieth-century concept. Everything and nothing has changed. 